\title{
KURIOS
}

(Jurnal Teologi dan Pendidikan Agama Kristen)

Vol. 3, No. 1, Oktober 2015 (22-39)

ISSN 2406-8306 (print)

http://www.sttpb.ac.id/e-journal/index.php/kurios

\section{Kritik dan Analisa Terhadap Pandangan Saksi Yehuwa Tentang Keilahian Yesus}

\author{
Eliman \\ Sekolah Tinggi Teologi Pelita Bangsa Jakarta
}

\begin{abstract}
Abstrak
Penulis membahas judul karya tulis ini karena sangat penting untuk dimengerti dan dipahami oleh umat Kristen secara khusus mengenai ke-Tuhanan Yesus, karena ada pandangan yang berbeda-beda dalam mengajarkan pribadi Yesus sehubungan dengan ke-Tuhanan-Nya. Secara khusus, dimana Saksi Yehuwa mempunyai pandangan teologis terhadap ke-Tuhanan Yesus yang menyatakan bahwa Yesus bukanlah Allah melainkan lebih rendah dari Allah Bapa, sehingga Saksi Yehuwa memahami dan mengajarkan bahwa Yesus adalah suatu allah, Yesus diciptakan oleh Allah sebagai ciptaan yang sulung dan Yesus adalah malaikat Mikhael, bahkan karya penebusan Yesus tidak sepenuhnya menghapus dosa umat manusia. Sedangkan, dalam teologi Kristen Protestan mempunyai pandangan terhadap ke-Tuhanan Yesus yang menyatakan bahwa Yesus adalah Allah dan sehakikat dengan Allah Bapa, sehingga Teologi Kristen Protestan mengajarkan bahwa Yesus adalah Allah, Yesus adalah pencipta, bahkan karya penebusan Yesus sepenuhnya menghapus dosa umat manusia dan menyediakan keselamatan bagi orang yang percaya kepada-Nya.
\end{abstract}

\section{Pendahuluan}

\section{Pandangan Saksi Yehuwa Terhadap Yesus}

Sejak munculnya Saksi Yehuwa yang menyatakan diri sebagai salah sate aliran dalam agama Kristen di Indonesia, maka timbul pandangan Kristologi yang berbeda dengan Kristologi Kristen Protestan, khususnya menyangkut keTuhanan Yesus Kristus. Konsep Saksi Yehuwa tentang keTuhanan Yesus Kristus menekankan bahwa Yesus bukanlah Allah, melainkan Yesus hanya sebagai suatu allah atau allah kecil yaitu allah yang lebih rendah dari Allah yang maha kuasa. Saksi Yehuwa membedakan kebesaran atau kekuasaan Yesus sebagai Allah yang perkasa (a mighty god) dengan kebesaran atau kekuasaan Allah sebagai Allah yang maha kuasa (The Almighty God). ${ }^{1}$ Dalam

\footnotetext{
${ }^{1}$ Majalah Saksi Yehuwa. Haruskah Anda Perccoyi Kepada Tritunggal. Jakarta: Perkumpulan Siswa-Siswa Alkitab. him. 16.
} 
pandangan Saksi Yehuwa, Yesus tidak pernah mengaku sebagai Allah, segala sesuatu yang Ia katakan tentang diriNya menunjukkan bahwa Ia tidak menganggap diriNya sama dengan Allah dalam hal apapun. ${ }^{2}$ Berulang kali Yesus menunjukkan bahwa Ia adalah makhluk yang lebih rendah dari Allah dan bahwa Ia, Yesus mempunyai Allah di atas diriNya, Allah yang Ia sembah, Allah yang Ia sebut 'Bapa'. ${ }^{3}$

Untuk memperkuat pandangan tersebut Saksi Yehuwa menunjukkan beberapa ayat yang membuktikan bahwa Yesus adalah makhluk yang lebih rendah dari Allah, dalam 2 Korintus 1:3 rasul Paulus menyatakan: "Terpujilah Allah, Bapa (dari) Tuhan kita Yesus Kristus", bagian ini memberikan pemahaman bahwa karena Yesus mempunyai Allah yaitu Bapa-Nya, Ia tidak mungkin pada waktu yang sama juga adalah Allah itu sendiri, bahkan Yesus menunjukkan bahwa Ia adalah pribadi yang lebih rendah dari Allah dengan mengatakan: "Mengapa kaukatakan Aku balk? Tak seorang pun yang baik selain dari pada Allah saja (Markus 10:18)", dalam ayat ini Yesus menjelaskan bahwa tidak ada pribadi lain manapun yang sebaik Allah, bahkan Yesus sendiri tidak.

Selanjutnya, Yesus juga menyatakan keunggulan BapaNya ketika ia berkata: "Roh Tuhan (Allah) ada padaKu, oleh sebab Ia telah mengurapi Aku, untuk menyampaikan kabar baik kepada orang-orang miskin (Lukas 4:18)" dan Pengurapan merupakan pemberian wewenang atau togas oleh orang yang lebib tinggi kepada seseorang yang masih belum mempunyai wewenang. Di sini Allah adalah jelas yang lebih unggul, karena Ia mengurapi Yesus dengan memberikan wewenang yang tidak ia miliki sebelumnya, kemudian keunggulan BapaNya semakin diperjelas, ketika ibu dari dua murid Yesus yaitu Yakobus dan Yohanes datang memohon agar putra-putranya masingmasing duduk di sebelah kanan dan di sebelah kiri Yesus bila ia memerintah dalam kerajaanNya. Yesus menjawab: "Hal duduk di sebelah kananKu atau di sebelah kiriKu, Aku tidak berhak memberikannya. Itu akan diberikan kepada orang-orang bagi siapa BapaKu (yaitu Allah) telah menyediakannya (Matius 20:23)." Jika Yesus adalah Allah yang Mahakuasa, ia berhak memberikan kedudukan tersebut, namun Yesus tidak dapat melakukannya karena itu adalah hak Allah dan Yesus bukan Allah.

Bahkan, di dalam 1 Korintus 15:24,28 juga menyatakan bahwa: "Kemudian tiba kesudahannya, yaitu bilamana Ia (Yesus) di surga menyerahkan Kerajaan kepada Allah Bapa...

\footnotetext{
${ }^{2}$ Majalah Menara Pengawal. 1994. Yesus Kristus Adalah Tuhan, Apakah benar dan Bagannana? Jakarta: Perkumpulan Siswa-Siswa Alkitab, 30

${ }^{3}$ Haruskah Anda Percaya Kepada Tritunggal. Op. Cit, 17.
} 
maka Ia sendiri sebagai Anak akan menaklukkan diriNya di bawah Dia, yang telah menaklukkan segala sesuatu dibawahNya, supaya Allah menjadi semua di dalam semua ${ }^{4}$, ayat ini memberikan pengertian bahwa di masa depan yang kekal Yesus akan tents menjadi hamba Allah yang lebih rendah dart Allah." Pandangan teologis Saksi Yehuwa terhadap keTuhanan Yesus juga dipertegas, seperti yang dikatakan oleh seorang penganut Saksi Yehuwa yang bernama Rylands dengan menyatakan bahwa:

Faktanya harms dihadapi bahwa penelitian Baru selama kira-kira tiga puluh atau empat puluh tahun belakangan iiii telah menuntut SeMakin banyak sarjana Perjanjian Baru kepada kesimpulan bahwa Yesus jelas tidak pernah inenganggap dirinya sendiri Allah, melainkan lebih rendah dart Allah. ${ }^{5}$

Oleh karena itu, Saksi Yehuwa mengajarkan bahwa Yesus adalah suatu allah yang lebih rendah dart Yehuwa, sebagaimana yang dikatakan oleh Kitab Suci Saksi Yehuwa 'Terjemahan Dunia Baru' dalam Yohanes 1:1 yang menyatakan "Pada mulanya Firman itu ada dan Firman itu bersama Allah dan Firman itu adalah suatu allah" dan Yesus adalah ciptaan sulung yang diciptakan oleh Yehuwa, sebagaimana yang dinyatakan dalam Kolose 1:15 berbunyi: "Dia adalah gambar Allah yang tidak kelihatan, ciptaan yang sulung dari antara semua ciptaan" dan Wahyu 3:14 mengatakan: "Ia adalah permulaan dari ciptaan Allah." Bahkan Saksi Yehuwa mempercayai dan mengajarkan bahwa Putra Yehuwa yaitu Yesus sebelum menjadi manusia adalah Malaikat Agung yang bernama Mikhael dan Saksi Yehuwa mengajarkan bahwa karya penebusan Yesus tidak sepenuhnya menghapus dosa umat manusia melainkan hanya membebaskan umat manusia dari dosa Adam saja dan Yesus bukan Juruselamat. ${ }^{6}$

\section{Pembahasan}

\section{Apakah Yesus adalah Malaikat Mikhael?}

Saksi Yehuwa memiliki pandangan teologis terhadap ke-Tuhanan Yesus yang menyatakan bahwa Yesus adalah Malaikat Mikhael, dimana Saksi Yehuwa mempercayai bahwa Putra Yehuwa yaitu Yesus sebelum menjadi manusia adalah Malaikat Agung yang bernama Mikhael. ${ }^{7}$ Bagaimana Saksi Yehuwa bisa yakin bahwa Malaikat Mikhael adalah

\footnotetext{
${ }^{4}$ Ibid. him 20. (Kutipan ayat-ayat di atas diambil dart Alkitab lerjemahan Dunia Baru', Kitab Suci Saksi Yehuwa).

${ }^{5}$ Bulletin of the John Rylands Library di Manchester, Inggris. 1989, 20

${ }^{6}$ H. Wayne House. 2006. Charts Of Cults, Sects And religious Movements 'Gerakan Keagamaan'. Cetakan Pertama. Malang: Gandum Mas, 180.

${ }^{7}$ H. Wayne House. 2006. Charts Of Cults, Sects And religious Movements `Gerakan Keagamaan Cetakan Pertama. Malang: Gandum Mas, 180.
} 
Yesus? Menurut Saksi Yehuwa, Alkitab memuat lima rujukan tentang makhluk roh yang perkasa bernama Mikhael; tiga diantaranya terdapat di kitab Daniel: dalam Daniel 10:13, 21 menyatakan bahwa seorang malaikat yang sedang bertugas diselamatkan oleh Mikhael yang disebut 'salah seorang dari antara para pangeran yang terkemuka dan pengeranmu'. Kemudian, dari Daniel 12:1 juga menyatakan bahwa pada zaman akhir 'Mikhael akan bangkit berdiri, pangeran besar yang sedang berdiri demi kepentingan putra-putra bangsamu'. ${ }^{8}$

Mikhael disebutkan lagi di dalam Kitab Penyingkapan (Wahyu) 12:7 yang menggambarkan 'Mikhael beserta malaikat-malaikatnya' sedang terlibat dalam peperangan sangat penting yang berakibat dicampakkannya Setan si Iblis beserta malaikat-malaikat fasiknya dari surga. Perhatikan bahwa dalam setiap konteks ayat-ayat tersebut, Mikhael dilukiskan sebagai malaikat pejuang yang berperang membela umat Allah dan melindungi mereka bahkan menghadapi musuh terbesar Yehuwa yaitu si Iblis. ${ }^{9}$

Selanjutnya, Yudas ayat 9 menyebut Mikhael "sang penghulu malaikat', kata 'penghulu' berarti 'ketua' atau 'kepala' dan dalam Alkitab, istilah 'penghulu malaikat' tidak pernah digunakan dalam bentuk jamak dan penghulu malaikat disebutkan hanya satu kali lagi yaitu di 1 Tesalonika 4:16, di ayat ini Paulus menggambarkan Yesus yang telah dibangkitkan, dengan mengatakan: 'karena Tuan (Yesus) sendiri akan turun dari surga dengan seruan yang kuat, dengan suara penghulu malaikat dan dengan terompet Allah. Maka, diayat ini Yesus sendiri disebut sebagai penghulu malaikat atau malaikat kepala. ${ }^{10}$

Bahkan, Yesus adalah sang penghulu malaikat Mikhael, karena kedua nama ini yaitu Mikhael berarti 'Siapa Seperti Yehuwa?' dan Yesus berarti 'Yehuwa Adalah Keselamatan" terlibat perannya sebagai pendukung kedaulatan Allah yang terkemuka, sebagaimana Filipi 2:9 menyatakan: "Allah meninggikan dia kepada kedudukan yang lebih tinggi dan dengan baik hati memberinya nama di atas setiap nama lain." ${ }^{11}$ Jadi, Mikhael sang penghulu malaikat adalah Yesus sendiri sebelum ia hidup sebagai manusia kemudian setelah ia coati dan dibangkitkan dalam bentuk roh, ia kembali ke surga dan tetap melanjutkan pelayanannya sebagai malaikat Mikhael, sang malaikat kepala bagi kemuliaan Allah, Sang Bapak (Filipi 2:11). ${ }^{12}$

Akan tetapi, Alkitab dengan jelas menyatakan bahwa dalam konteks penghulu

\footnotetext{
${ }^{8}$ Majalah Menara Pengawal. 2010. Pria (Yesus) Yang Mengubah Dunia. Jakarta: Perkumpulan SiswaSiswa Alkitab., 19.

${ }^{9}$ Ibid

${ }^{10}$ Ibid., 20

${ }^{11}$ Ibid.

${ }^{12}$ Majalah Sedarlah. 1999. Apa Kebenaran Tentang Malaikat Mikhael. Jakarta: Perkumpulan SiswaSiswa Alkitab, 10.
} 
malaikat yang bernaina hanya muncul tiga kali dalam Perjanjian Lama pada kitab Daniel 10:13;21 dan 12:1 sedangkan dalain Perjaujian Baru nama MIKHAEL hanya minimal dua kali pada Yudas 1:9 dan Wahyu 12: 7, 11(dari kelima ayat ini ada satu ayat pun yang menyamakan Tuhan Yesus)

\section{Kristus dengan Malaikat yang Bernama Mikhael ${ }^{13}$}

Selanjutnya, di dalam kitab Daniel 10:13,21 dan 12:1 dijelaskan bahwa pada waktu Daniel berdoa selama tiga minggu itulah, datang cpemimpin kerajaan orang Persia' berdiri menentang Kristus; istilah pemimpin (Ibrani: `sar') di sini menunjuk kepada cpemimpin spiritual' (bdk ayat 20- 'sar orang Yunani; ayat 21 Malaikat Mikhael sebagai 'sar orang Israel, bdk Yudas 1:9). Jadi pemimpin orang Persia' yang dimaksud bukanlah menunjuk kepada raja Persia melainkan utusan iblis yang disembah oleh orang Persia dan iblis ingin menghalangi Daniel yang akan didatangi oleh Kristus untuk membuka rahasia nubuat Allah, namun Malaikat Mikhael salah seorang dari cpemimpin termuka' artinya penghulu malaikat datang memberikan pertolongan. ${ }^{14}$

Akhirnya, malaikat Mikhael diutus Kristus untuk berperang melawan utusanutusan iblis yang disembah oleh raja Persia dan jelas peperangan rohani ini dimenangkan oleh Malaikat Mikhael (bdk: ayat 13,20-21;Yud 1:9; Wyh 12:7-9), karena malaikat Mikhael adalah 'penghulu malaikat' yang dikenal sebagai 'malaikat perang' yang menjadi hamba Kristus yang siap membantu, sehingga Kristus bisa mendatangi Daniel dalam 'theophany-Nya' sebagai manusia ilahi yang luar biasa mulia (ayat 13b). Kemudian sekali lagi, di ayat 14 tujuan kedatangan Kristus kepada Daniel dijelaskan bahwa untuk membantu Daniel mengerti nubuat penglihatan dari Allah kepadanya tentang bangsanya yaitu bangsa Yahudi di hari-hari mendatang. ${ }^{15}$

Selanjutnya, Yudas 1:9 dengan tegas menulis bahwa Mikhael adalah "penghulu malaikat", yang artinya pemimpin dari sejumlah malaikat, oleh karena itu, tidak benar bahwa Firman Allah berbicara bahwa hanya ada satu penghulu malaikat, sebab dalam Daniel 10:13 disebutkan Mikhael adalah salah satu dari para pemimpin Israel, dan di dalam literatur Yahudi disebutkan bahwa Mikhael hanya salah satu dari tujuh penghulu malaikat (Henokh 20:5;89:76) yang menjadi pemimpin Israel. ${ }^{16}$ Bahkan, malaikat itu

\footnotetext{
${ }^{13}$ Eddy Fances. Wahyu Allah Kepada Nabi Daniel. (Cetakan Pertama. Jakarta: Yayasan Sinar Nusantara. 2005),. 214

${ }^{14}$ Ibid., 215.

15 Ibid., 216. 290.
} 
banyak sekali jumlahnya (Mazmur 68:18; Ibrani 12:22) dan rupanya ada tingkatantingkatan di antara malaikat, ada dua malaikat yang lebih tinggi daripada yang lain yaitu Mikhael dan Gabriel; Mikhael merupakan utusan istimewa bagi bangsa Israel yang bertugas berperang melawan si jahat (Daniel 1:13, 21; 12:1; Why. 12:7) sedangkan Gabriel adalah malaikat yang bertugas membawa berita dari Allah (Daniel 8:16-26; Lukas 1:19,26).

Selanjutnya, Kitab suci menceritakan malaikat dengan macam-macam nama yang terbanyak disebut 'roh' tetapi juga sering disebut dengan nama seperti Kerub, Serafim, Gabriel, Raphael, Uriel, Hananiel dan Mikhael yang menjadi pembesar balatentara surga serta merupakan pembantu terdekat Allah, sebagaimana yang dinyatakan Eddy Fances dalam bukunya, menyatakan bahwa: Ketujuh malaikat merupakan pembantu terdekat Allah, yakni: Gabriel, Kerub, Serafim, Raphael, Uric!, Hananiel dan Mikhael; para malaikat ini diciptakan bukan saja untuk melayani Allah melainkan juga inelayani orang-orangpercaya yang diselamatkan Allah (Mat. 18:10; Ayub 1:10). ${ }^{17}$

Dari pernyataan diatas memberikan pemahaman bahwa malaikat Mikhael merupakan malaikat pembantu terdekat Allah dan Yesus bukanlah Malaikat Mikhael. Kemudian, 1 Tesalonika 4:16 benar berbicara mengenai Yesus yang bangkit yang turn dari surga sebagai Tuhan (TB-LAI, ini direndahkan oleh Saksi Yehuwa dalam terjemahan NW menjadi sekedar TUAN), namun 1Tes. 4:16 tidak mengindikasikan bahwa Yesus itu penghulu malaikat. Kalau mau menafsirkan bahwa 'Yesus sendiri yang berseru dengan suara penghulu malaikat dan ditafsirkan kalau begitu Yesus adalah penghulu malaikat,' maka konsekwensinya ayat itu juga harus ditafsirkan bahwa 'Yesus sendiri berseru dengan terompet Allah seharusnya juga ditafsirkan kalau begitu Yesus adalah Allah' namun ini tidak dilakukan oleh Saksi Yehuwa, sehingga dalam ayat itu Yesus yang bangkit datang sebagai Tuhan diiringi suara penghulu malaikat dan terompet Allah, keduanya terlepas dari diri-Nya. ${ }^{18}$

Bahkan, Saksi Yehuwa juga menyebut bahwa Mikhael artinya 'Slapa Seperti maka karena Saksi Yehuwa mengajarkan bahwa Yesus bukan Allah tetapi seperti Allah, maka dianggap Yesus adalah Mikhael. Dalam Alkitab jelas tertulis bahwa Yesus bukan `seperti Allah' atau suatu Allah' (seperti terjemahan Yoh.1 : 1 dalam NW), melainkan 'Ye sus adalah Allah' yang lebih superior daripada Mikhael.' Ini jelas terlihat dalam kitab Ibrani: "Karena kepada siapakah di antara malaikat-malaikat itu pernah Ia katakan: "Anak-Ku

\footnotetext{
${ }^{17}$ Eddy Fances, Surat Kepada Orang Ibrani (Cetakan Pertama. Jakarta: Yayasan Sinar Nusantara. 2004), 25. 51.

${ }^{18}$ Gary Kinnaman, Malaikat di Sekitar Kita (Cetakan Ketiga. Yogyakarta: Yayasan ANDI, 2007),
} 
Engkau! Engkau telah Kuperanakkan pada hari ini?" dan "Aku akan menjadi BapaNya, dan Ia akan menjadi Anak-Ku?" (Ibr. 1 :5), ayat ini menunjukkan bahwa Yesus bukan malaikat dan tidak sama dengan Mikhael. ${ }^{19}$ Dari semua penjelasan di atas, maka dapat disimpulkan bahwa kekeliruan di dalam penafsiran terhadap Firman Tuhan merupakan kesalahan yang dilakukan oleh Saksi Yehuwa dengan menafsirkan Dan 10: 13,21; 12: 1 ;Why 12:7 dan Yud ayat 9 merujuk bahwa kelima ayat ini menyatakan bahwa Yesus adalah malaikat Mikhael, padahal Alkitab dengan jelas menyatakan bahwa dari kelima ayat tersebut tidak ada sate ayat pun yang menyamakan Tuhan Yesus Kristus dengan Malaikat yang bernama Mikhael. ${ }^{20}$

Selanjutnya, Yesus Kristus disebut lebih besar dari semua malaikat termasuk Mikhael: "Seinua malaikat Allah hams menyembah Dia ." Bandingkan ini dengan para malaikat yang tidak mau disembah dalam Wahyu 22:8-9 yang berbunyi:" Dan aku, Yohanes, akulah yang telah mendengar dan melihat semuanya itu. Dan setelah aku mendengar dan melihatnya, aku tersungkur di depan kaki malaikat, yang telah menunjukkan semuanya itu kepadaku, untuk menyembahnya. Tetapi is berkata kepadaku: "Jangan berbuat demikian! Aku adalah hamba, sama seperti engkau dan saudara-saudaramu, para nabi dan semua mereka yang menuruti segala perkataan kitab ini. Sembahlah Allah!" Karena itu, hanya Allah yang patut disembah dan malaikat tidak, karena Yesus mau disembah bahkan oleh malaikat yang lebih tinggi dari manusia, maka jelas 'Ye sus adalah Allah dan bukan malaikat Mikhael. ${ }^{21}$ Jadi, Yesus tidak pernah menjadi Mikhael sang malaikat penghulu sebelum Dia datang ke dunia, dan tidak pernah bangkit sebagai "seorang makhluk roh"malaikat Mikhael, karena Alkitab dengan jelas menyatakan bahwa Yesus bukanlah malaikat Mikhael, Yesus benar-benar bangkit dari kematian dan Ibrani 2:5 menyatakan: "Sebab bukan kepada malaikat-malaikat telah Ia taklukkan dunia yang akan datang, yang kita bicarakan ini". ${ }^{22}$

\section{Apakah Yesus bukan Allah Melainkan suatu allah (Yohanes 1:1)?}

Saksi Yehuwa memiliki pandangan teologis bahwa Yesus adalah suatu allah, bukan Allah Yang Maha Kuasa, sebagaimana dalam Kitab Suci Saksi Yehuwa 'Terjemahan Dunia Baru' Yohanes 1:1 berbunyi: "Pada mulanya Firman itu ada dan Firman itu bersama Allah dan Firman itu adalah suatu allah". Ayat ini berbunyi bahwa

\footnotetext{
${ }^{19}$ Ibid., 54.

${ }^{20}$ Eddy Fances. Loc. Cit.

${ }^{21}$ Gary Kinnaman. Loc. Cit.

${ }^{22}$ Eddy Fances. Surat Kepada Orang Ibrani. Op. Cit., 27.
} 
'Firman itu bersamasama dengan Allah' seseorang yang 'bersama-sama' dengan pribadi lain tidak mungkin sama dengan pribadi yang lain itu, dengan kata lain bahwa seseorang yang sedang bersama-sama dengan orang lain tidak mungkin sekaligus orang itu juga. ${ }^{23}$ Selanjutnya, menurut Saksi Yehuwa dalam Yohanes 1:1 kata benda Yunani the-os' (allah) muncul dua kali, yang pertama memaksudkan Allah Yang Mahakuasa dengan siapa Firman itu ada bersama-sama (Firman itu lo'gos) bersama-sama dengan Allah (bentuk dari theos). The-os yang pertama didahului oleh kata ton (bahasa Inggris 'The') suatu bentuk kata sandang tertentu bahasa Yunani yang menunjukkan kepada identitas yang pasti, dalam hal ini Allah Yang Mahakuasa (Firman itu bersama-sama dengan Allah (bahasa Inggris 'The God'). ${ }^{24}$

Sebaliknya, menurut Saksi Yehuwa bahwa tidak ada kata sandang di depan kata the-os yang kedua dalam Yohanes 1: 1, jadi terjemahan yang aksara akan berbunyi "Firman itu allah". Namun Saksi Yehuwa telah melihat banyak terjemahan menyebutkan the-os (kata benda yang menjadi predikat) yang kedua ini sebagai 'bersifat ilahi,' seperti allah atau suatu allah. Bahasa Yunani Koine mempunyai kata sandang tertentu (bahasa Inggris 'The') namun tidak memiliki kata sandang tidak tentu (bahasa Inggris 'a atau an' atau suatu), jadi bila sebuah kata benda yang menjadi predikat tidak didahului oleh kata sandang tertentu bisa jadi ini tidak tentu bergantung ikatan kalimatnya. ${ }^{25}$

Sehubungan dengan hal di atas, Journal of Biblical Literature berkata bahwa istilah-istilah 'yang mempunyai predikat (tanpa kata sandang) yang mendahului kata kerja, terutama mengandung arti kualitatif (menunjukkan sifat sesuatu), seperti dikatakan Journal ini menunjukkan bahwa Lo-gos bisa disamakan dengan suatu allah dan juga dikatakan tentang Yohanes 1:1: "Kekuatan kualitatif dari predikatnya begitu menonjol sehingga kata bendanya (the-os) tidak dapat dianggap tertentu. ${ }^{26}$

Jadi Yohanes 1:1 menonjolkan sifat dari Firman bahwa is 'ilahi' seperti allah atau suatu allah, namun bukan Allah Yang Mahakuasa. Ini selaras dengan ayat-ayat lain dalam Alkitab yang menunjukkan bahwa Yesus yang disini disebut 'Firman' dalam peranannya sebagai Juru Bicara Allah, adalah suatu pribadi lebih rendah yang taat, diutus ke bumi oleh AtasanNya yaitu Allah Yang Mahakuasa. ${ }^{27}$ Akan tetapi, teologi Kristen Prostestan memiliki pandangan bahwa Yesus adalah Allah, sebagaimana yang dinyatakan dalam

${ }^{23}$ Haruskah Anda Percaya Kepada Tritunggal. Op. Cit., 27

24 Ibid.

${ }^{25}$ Ibid.

${ }^{26}$ Ibid., 28.

${ }^{27}$ Ibid. 
Yohanes 1:1 berbunyi: "Pada mulanya adalah Firman; Firman itu bersama-sama dengan Allah dan Firman itu adalah Allah" yang ditegaskan di sini adalah mengenai Logos atau Firman bahwa Ia bukan hanya bersama-sama dengan Allah tetapi Ia adalah Allah (theos en ho logos), bentuk kalimat ini memperlihatkan bahwa Yohanes bermaksud untuk mengatakan bahwa Allah adalah Firman dengan penekanan pada kata Allah dan tidak hanya menyatakan bahwa Firman itu bersifat Tidak adanya kata sandang 'ho' memperlihatkan bahwa theos merupakan predikat (sebutan) dan bukan kata sifat, karena itu pernyataan ini merupakan keterangan penting dalam memperlihatkan bahwa Yesus adalah Allah, dimana 'ho logos (Firman)' adalah merupakan subjek dan tidak adanya artikel atau kata sandang 'ho' pada 'theos (Allah)' berarti berfungsi menunjuk bahwa Firman itu sama esensinya atau hakikat/ zat atau kualitasnya dengan Allah, karena Firman itu adalah Allah. ${ }^{28}$

Yohanes memakai kata Logos yaitu Firman untuk identitas Allah yang berinkarnasi dalam diri Yesus karena Pribadi Yesus adalah sehakikat dengan Allah, pemakaian kata 'Firman' diperkirakan tercatat kira-kira tiga ratus kali dalam Perjanjian Baru tetapi di luar Yohanes pasal 1 dan Wahyu 19:13 (dan mungkin beberapa ayat lain yang sulit ditafsirkan) dan kata ini mempunyai arti seperti "kata, hal, akal, alasan dan pertanggungjawaban" yaitu arti-arti yang jelas berbeda dari apa yang dimaksudkan oleh Yohanes dalam nast ini, di mana Firman itu adalah seorang pribadi, karena jenis pada kata Firman dalam Yohanes 1:1 ini adalah maskulin yang menunjuk pada pribadi bukan suatu atau sesuatu. $^{29}$

Di dalam Alkitab terjemahan dalam bahasa Inggris baik NIV maupun NKJV Injil Yohanes 1:1 menyatakan: "In the beginning was the Word, and the Word was with God, an the Word was God (Pada mulanya adalah Firman, Firman itu bersama-sama dengan Allah, dan Firman itu adalah Allah)" namun Saksi Yehuwa menerjemahkan bagian terakhir dari Yohanes 1:1 sebagai 'The Word was a god (Firman itu adalah suatu allah) ${ }^{30}$ akan tetapi, jika ditinjau dari sudut tata bahasa Yunani kalimat itu terjemahannya memang 'The Word was God bukan The Word was a god'.

Bahkan, Alkitab LAI Terjemahan Lama menyatakan bahwa: "Maka pada awal pertama adalah Firman, dan Firman itu bersama-sama dengan Allah, dan Firman itulah juga Allah" karena, urutan kalimat dalam bahasa Yunani tidak seperti bahasa Indonesia

\footnotetext{
${ }^{28}$ Donald Guthrie. Teologi Perjaujian Barn Jilid I. (Cetakan Pertama. Jakarta: BPK Gunung Mulia, 1991), 383

${ }^{29}$ Dave Hagelberg, Tafsiran Injil Yohanes Pasal 1-5 Dart Bahasa Yunani. (Cetakan Pertama. Yogyakarta: Yayasan ANDI, 1999),. 32.

${ }^{30}$ James Hope Moulton.. A Grammar of New Testament Greek Vol III. 1976, 183.
} 
ataupun Inggris, bahwa mesti subyek baru predikat, struktur kalimat Yunani berbeda, apa yang ada di muka adalah yang merupakan penekanan. Jadi Yohanes menekankan hakekat ho logos adalah theos (Allah), sehingga dalam penulisannya kata theos diletakkan di depan.

Ungkapan theos en ho logos, "Firman itu adalah Allah" menyatakan bahwa Sang Firman (Yesus Kristus) memiliki ousia (hakekat/zat) Allah. Kata theos menggunakan nomina, bukan kata sifat (adjektiva) dan menekankan pada ke-Allahan Yesus Kristus. ${ }^{31}$ Hal ini dikarenakan, di dalam bahasa Yunani ada yang disebut dengan kalimat complement, sebagaimana yang dinyatakan oleh Halim Wiryadinata dalam bukunya menyatakan bahwa: "Kalimat complement dapat ditemukan di dalam bahasa Yunani dan menurut Wenham dikatakan bahwa kalimat complement yaitu kalimat yang Amnia definite article (kata sandang) pada kata tersebut sebagai nominative (subjek). Dengan kata lain, jika kata sandang 'ho' berada di depan swam kata tersebut, maka kata yang mempunyai kata sandang itu menjadi nominative atau subjeknya."32

Dari pernyataan di atas, jelaslah bahwa Yohanes 1:1 menulis ckai theos en ho logos' maka terjemahannya yaitu "Firman itu adalah Allah" bukan "Allah adalah firman" karena ho logos adalah merupakan subjek dari kalimat tersebut dan tidak kata sandang 'ho' pada 'theos' berarti berfungsi menunjuk bahwa Firman itu sama esensinya atau hakikat/ zat atau kualitasnya dengan Allah, karena Firman itu adalah Allah. ${ }^{33}$ Oleh karena itu, pandangan Saksi Yehuwa adalah pandangan yang salah karena hal ini merupakan sesuatu yang bodoh, dimana Saksi Yehuwa ingin membuktikan bahwa Yesus bukanlah Allah Yang Mahakuasa dengan menggunakan Yohanes 1:1, tetapi pada waktu mereka menafsirkan Yoh 1:1 dengan berdasarkan asumsi atau anggapan mereka bahwa Yesus bukanlah Allah Yang Mahakuasa sehingga Yesus dianggap sebagai suatu allah yang lebih rendah dari Allah Bapa. ${ }^{34}$ Sebaliknya, pandangan teologi Kristen Protestan adalah pandangan yang benar karena menafsirkan Yohenas 1:1 bahwa Firman itu adalah Allah, sebagaimana yang dinyatakan oleh Yohanes bahwa pemakaian kata Logos yaitu Firman untuk identitas Allah yang berinkarnasi dalam diri Yesus karena Pribadi Yesus adalah sehakikat dengan Allah dan Firman itu adalah Allah. ${ }^{35}$

\footnotetext{
${ }^{31}$ Ibid., 184.

${ }^{32}$ Halim Wiryadinata, Hikmat Kristus. (Cetakan Pertama. Jakarta: JATS, 2003), 57.

${ }^{33}$ Ibid.

${ }^{34}$ Herlianto, Saksi Yehuwa Siapa dan Bagaimana Mereka? (Cetakan kelima. Bandung: Yayasan Kalam Hidup, 2002), 43

${ }^{35}$ Ibid, 45
} 


\section{Apakah Yesus Diciptakan oleh Allah dan Yesus adalah Juruselamat?}

Dalam pandangan teologis Saksi Yehuwa terhadap ke-Tuhanan Yesus dipahami bahwa Yesus diciptakan oleh Allah (Yehuwa), sebagaimana yang dinyatakan dalam Kitab Suci Saksi Yehuwa 'Terjemahan Dunia Baal' Kolose 1:15 berbunyi: "Dia adalah gambar Allah yang tidak kelihatan, ciptaan yang sulung dari antara semua ciptaan" dan Wahyu 3:14 mengatakan: "Ia adalah permulaan dari ciptaan Allah." 'Permulaan' (bahasa Yunani: ar-khe') tidak dapat ditafsirkan bahwa Yesus adalah 'pemula' dari ciptaan Allah, dalam tulisan-tulisannya di Alkitab Yohanes menggunakan berbagai bentuk dari kata Yunani ar-khe lebih dari 20 kali dan ini selalu mempunyai arti umum 'permulaan'. Ya, Yesus diciptakan oleh Allah sebagai ciptaan sulung permulaan dari ciptaanciptaan Allah yang tidak kelihatan. ${ }^{36}$

Perhatikan betapa erat hubungan antara acuan-acuan kepada asal usul Yesus dengan pernyataan-pernyataan yang diungkapkan oleh 'hikmat' kiasan dalam buku Amsal di Alkitab: "TUHAN (Yahweh) telah menciptakan aku sebagai permulaan pekerjaan-Nya yang paling awal dari hasil-hasil pekerj aan-Nya di masa lampau aku telah dibentuk, ditetapkan sejak permulaan, sejak masa yang lebih awal daripada bumi (Amsal 8:22-23), meskipun istilah 'hikmat' digunakan untuk mempersonifikasi pribadi yang Allah ciptakan, Saksi Yehuwa setuju bahwa istilah 'hikmat' menunjuk kepada Ye sus sebagai ciptaan sulung makhluk roh sebelum hidup sebagai manusia. $\mathbf{u}^{\circ}$ Akan tetapi, pandangan teologi Kristen Protestan tidak mengajarkan bahwa Yesus diciptakan oleh Allah, karena Yesus Kristus sudah ada dari kekal bersama-sama dengan Allah Bapa (Yohanes 1:2) dan pada waktu Dia dilahirkan adalah sebagaimana 'Firman Keluar' ketika Allah berfirman, Allah bertindak sebagai Yang Berkata-kata dan Allah menyatakan diriNya melalui Firman yang dikeluarkanNya kemudian Firman yang keluar itu menjadi manusia dan Ia adalah Pribadi kedua yaitu Yesus Kristus yang sehakikat dengan Allah Bapa (Yohanes 1:14). ${ }^{37}$

Selanjutnya, Yesus yang sudah ada bersama-sama dengan Bapa di dalam kekekalan telah ditetapkan bahwa Dialah yang menciptakan dunia dan segala sesuatu, dengan pengertian lain bahwa oleh karena Dia (Yesus) dunia dan segala sesuatu diciptakan (Yohanes 1:3). Bandingkan dengan Kolose 1:16 yang menyatakan bahwa: "Karena di dalam Dialah telah diciptakan segala sesuatu, ...segala sesuatu diciptakan oleh Dia dan untuk Dia" Di sini lebih jelas bahwa segala sesuatu bukan saja diciptakan melalui dan oleh

\footnotetext{
${ }^{36}$ Harttskah Anda Percaya Kepada Tritttnggal. Op. Cit., 14.

${ }^{37}$ Stephen Tong. Op. Cit., 63.
} 
Dia, tetapi juga bagi Dia. Segala sesuatu diciptakan oleh Yesus; ini berarti pribadi kedua mengerjakan pekerjaan pribadi pertama dan mengerjakannya bersama-sama. ${ }^{38}$

Jadi kedua pribadi bukan saja mempunyai esensi ilahi yang sama, tetapi juga mempunyai pekerjaan yang sama dan siapakah yang dapat menciptakan kecuali Allah sendiri? hanya Allahlah yang dapat menciptakan! Jadi, kalau di sini dikatakan Firman itu (Yesus) menciptakan segala sesuatu, berarti Yesus adalah Pencipta dan jelaslah bahwa Yesus adalah Allah, sebagaimana yang dinyatakan Yohanes 1:1 bahwa Yesus Kristus adalah Allah dan dipertegas di dalam Yohanes 1:3 (dan Kolose 1:16), dimana dikatakan Dia (Yesus) melakukan pekerjaan menciptakan segala sesuatu. ${ }^{39}$ Di dalam Alkitab memberikan keterangan yang jelas bahwa konteks Kolose 1:15-19 adalah satu perikop yang menyatakan bahwa Yesus adalah sebagai "Pencipta segala sesuatu, Yesus bukan ciptaan." ${ }^{40}$ Memang jika hanya melihat pada satu ayat (ayat 15) yang berdiri sendiri seakan-akan terlihat bahwa Yesus adalah ciptaan pertama, tetapi jika melihat pada keseluruhan ayat, konteksnya akan jelas terlihat bahwa Yesus adalah sang pencipta bukan ciptaan:

"Karena di dalam Dialah telah diciptakan segala sesuatu, yang ada di sorga dan yang ada di bumi, yang kelihatan dan yang tidak kelihatctn, baik singgasanct, mattpun kerajaan, balk pemerintcth, mattpun pengttasa; segala sesuatu diciptctkan oleh Dia dan untuk Dia. Ia ada terlebih dahulu dari segala sesuatu dan segala sesuatu ada di dalam Dia. Ialah kepctla tubuh, yaitu jemaat. Icticth yang suiting, yang pertama bangkit dari antara orang nutti,,cehingga Ia yang lebih utama dalcini segala sesuatu. Karelia selttruh kepenuhan Allah berkenan diam di dalam Dia' (ayat 16-19).

Salah satu manipulasi terjemahan yang terdapat dalam Alkitab Saksi Yehuwa $(\mathrm{NW}=$ Terjemahan Dunia Baru) untuk menunjang ajaran bahwa Yesus adalah ciptaan dan dijadikan rekan pencipta oleh Allah untuk menciptakan yang lainnya adalah dengan menambahkan kata 'other' (yang lainnya) sesudah 'all' (segala sesuatu), ${ }^{41}$ sehingga memberi kesan yang berbeda tentunya, dimana terjemahan tersebut menyatakan bahwa: Karena di dalam Dialah telah diciptakan segala sesuatu, yang ada di sorga dan yang ada di bumi, yang kelihatan dan yang tidak kelihatan, baik singgasana, maupun kerajaan, baik pemerintah, maupun penguasa; segala sesuatu diciptakan oleh Dia dan untuk Dia. Ia ada

\footnotetext{
38 Ibid., 65.

${ }^{39}$ Ibid.

${ }^{40}$ Manfred T Brauch., Ucapan Paulus yang Suitt. (Cetakan Pertama. Malang: Seminari Alkitab Asia Tenggara, 1999), 230

${ }^{41}$ Herlianto. Op. Cit., 49.
} 
terlebih dahulu dari segala sesuatu dan segala sesuatu ada di dalam Dia. Ialah kepala tubuh, yaitu jemaat. Ialah yang sulung, yang pertama bangkit dari antara orang mati, sehingga Ia yang lebih utama dalam segala sesuatu. Karena seluruh kepenuhan Allah berkenan diam di dalam Dia (Kolose 1:16-19).

Dari pernyataan kutipan yang diambil dari Kitab Suci Saksi Yehuwa di atas memberikan pemahaman bahwa Yesus adalah ciptaan dan dijadikan rekan penciptaan oleh Allah. Bahkan, kesalahan yang mendasar dari penafsiran Saksi Yehuwa terhadap Kolose 1:15, selain tidak memperhatikan konteks, adalah memaksakan arti yang sempit kepada kata "sulung" dalam bahasa aslinya, "sulung" berasal dari kata prototokos (Yunani) sehingga Saksi Yehuwa menafsirkan bahwa Yesus disebut "sulung" karena Ia adalah ciptaan yang pertama, memang kata prototokos bisa dipakai dalam pengertian "yang pertama" dalam arti "lahir pertama" tetapi seperti yang telah dibahas di atas, hal itu bertentangan sekali dengan konteks perikop ini, karena kata prototokos dapat memiliki banyak pengertian yang lain." 42

Dalam Perjanjian Lama, konsep prototokos sama dengan konsep "hak kesulungan," yaitu hak yang membuat seorang anak prominen dan utama dibandingkan saudarasaudaranya. Dan "hak kesulungan" ini tidak hams jatuh kepada anak pertama. Jika ada alasan yang tepat, seorang ayah dapat memberikan hak kesulungan kepada anak yang lain (misal Yakub memberikannya kepada Yusuf, bukan Ruben. Abraham memberikannya kepada Ishak, bukan Ismael). Mereka yang menerima "hak kesulungan," mendapatkan warisan dua kali lebih banyak dibandingkan anak-anak yang lain. Jadi, konsep "sulung" dalam Perjanjian Lama lebih menekankan kepada keutamaan dan hak-hak khusus, dan tidak harus pada siapa yang lahir terlebih dahulu. ${ }^{43}$

Demikian juga, dalam Perjanjian Baru, prototokos memiliki pengertian lebih dari sekedar "lahir pertama" Oleh karena itulah, Lembaga Alkitab Indonesia menterjemahkan frase itu menjadi "yang sulung, lebih utama dari segala yang diciptakan." Agar tidak adakeragu-raguan, Paulus memberitahu orang-orang Kolose, mengapa Yesus disebut sulung: "karena di dalam Dialah telah diciptakan segala sesuatu." Paulus tidak berkata bahwa Yesus adalah sulung karena Ia yang pertama diciptakan. Sebaliknya, Yesus adalah prototokos karena Ia adalah pencipta segala sesuatu! Jelas bahwa kata prototokos dalam ayat ini tidak mengindikasikan bahwa Yesus adalah ciptaan pertama, melainkan Yesus adalah pribadi yang paling utama dalam alam semesta ini (Kol. 1:18) dan Yesus bukanlah

\footnotetext{
${ }^{42}$ Ibid.

${ }^{43}$ Manfred T Brauch. Op. Cit., 233
} 
ciptaan melainkan Yesus adalah Sang Pencipta. ${ }^{44}$ Hal ini dipertegas oleh Gavin Reid, dalam bukunya yang menyatakan bahwa "Yang Sulung: bukan berarti yang pertama diciptakan melainkan Yesus adalah ahli waris yang posisinya unik dan pribadi yang paling utama dalam alam semesta ini". ${ }^{45}$

Selanjutnya, Wahyu 3:14 merupakan ayat yang dipakai sebagai dasar oleh orang-orang Saksi Yehuwa untuk mengajarkan bahwa Yesus adalah ciptaan pertama dari Allah Bapa, karena ayat ini menyebut Yesus sebagai cpermulaan ciptaan Allah (the beginning of the creation of God)' akan tetapi, kebenaran Alkitab menjelaskan bahwa dalam kata Bahasa Yunani yang diterjemahkan cpermulaan' adalah 'Arche' dan kata arche ini mempunyai banyak arti seperti: beginning (permulaan/mulanya), ruler/ chief (pemerintah/kepala), origin (asal usul) dan source (sumber) dan bagian ini tidak boleh diartikan bahwaYesus adalah ciptaan pertama karena ini berarti Yesus bukan Allah. ${ }^{46}$ Oleh karena itu, Alkitab terjemahan LAI dalam bahasa Inggris NIV mengambil arti yang kedua yaitu ruler/chief, NIV menterjemahkan Wahyu 3:14 "... the ruler of God's creation (pemerintah atau kepala dari ciptaan Allah)" dan terjemahan ini tidak menunjukkan Yesus sebagai ciptaan Allah tetapi sebagai pemerintah/kepala dari ciptaan Allah! ${ }^{47}$ Bahkan, bisa juga mengambil arti ketiga dan keempat yang dengan demikian Wahyu 3:14 ini menunjukkan Yesuslah sebagai `somber' dari segala ciptaan Allah atau casal mula' dari ciptaan Allah, jadi Allah mencipta segala sesuatu melalui Yesus (bdk Yoh 1:3; Ibr 1:2b) dan dengan demikian Wahyu 3:14 ini tidak menunjukkan Yesus sebagai ciptaan Allah melainkan Yesus adalah sebagai Sang Pencipta. ${ }^{48}$

Sehubungan dengan yang di atas, Saksi Yehuwa juga menggunakan Amsal 8:22-23 bahwa hikmat menunjuk kepada Yesus adalah mahkluk yang diciptakan oleh Allah dan Yesus bukanlah Allah karena Amsal 8:22 mengatakan bahwa Hikmat itu dicipta dan pada ayat 23 juga menyatakan bahwa hikmat itu dibentuk oleh Allah; oleh karena itu, Saksi Yehuwa menganggap ini semua adalah sebagai bukti bahwa Yesus tidak kekal karena Yesus diciptakan oleh Allah. ${ }^{49}$ Akan tetapi, kebenaran Alkitab menjelaskan bahwa Amsal 8:22

\footnotetext{
44118 Ibid. him. 234.

45119 Gavin Reid. 2004. Handbook To The Bible. Cetakan Kedua. Bandung: Yayasan Kalam Hidup. him 691.

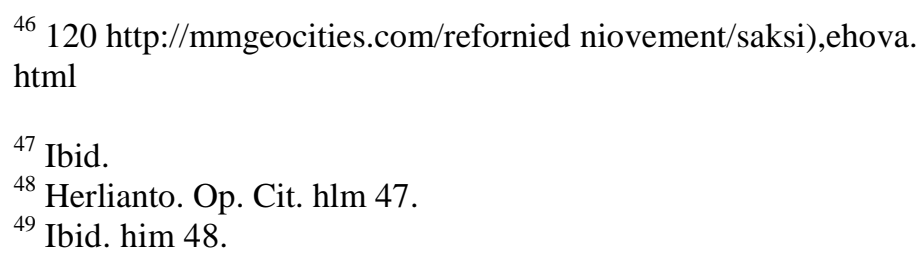


"TUHAN telah menciptakan aku sebagai permulaan pekerjaan-Nya, sebagai perbuatanNya yang pertama-tama dahulu kala" dan kata bahasa Yunani yang diterjemahkan `telah menciptakan aku' adalah Qanani yang berasal dari kata dasar Qanah yang sekalipun bisa diterjemahkan to create (mencipta) tetapi juga mempunyai bermacam-macam arti yang lain seperti to get (mendapatkan), to erect (menegakkan), to found (mendirikan), to buy (membeli) dan to posses (memiliki); Alkitab terbitan LAI baik terjemahan KJV, NASB dan NIV menterjemahkan 'possesed' yaitu memiliki, hal itu terlihat dalam terjemahan NIV yang menyatakan "The LORD possessed me at the beginning of his work, before his deeds of old (TUHAN memiliki aku pada permulaan pekerjaan-Nya, sebelum tindakan-tindakanNya pada jaman dahulu) dan juga KJV serta NASB jelas sama sekali tidak menunjulckan bahwa Yesus itu dicipta. ${ }^{50}$

Selanjutnya, Alkitab juga menjelaskan tentang Amsal 8:23 "Sudah pada zaman purbakala aku dibentuk, pada mula pertama, sebelum bumi ada" kata Ibrani yang diterjemahkan 'aku dibentuk' adalah 'Nissakti' yang arti sesungguhnya adalah 'I was appointed (aku ditentukan atau ditetapkan) dan Alkitab terjemahan NIV menyatakan " I was appointed from eternity, from the beginning, before the world began (Aku telah ditetapkan sejak kekekalan, dari semula, sebelum dunia ada), maka terjemahan ini lagi-lagi tidak menunjukican bahwa Yesus itu dicipta atau dibentuk. ${ }^{51}$ Oleh karena itu, jelaslah bahwa pandangan teologis Saksi Yehuwa yang menyatakan bahwa Yesus diciptakan oleh Allah adalah pandangan yang salah karena tidak sesuai dengan kebenaran Alkitab, sedangkan pandangan teologi Kristen Protestan adalah pandangan yang sesuai dengan kebenaran Alkitab bahwa Yesus tidak diciptakan melainkan Yesus Kristus sudah ada dari kekal bersama-sama dengan Allah Bapa (Yohanes 1:2) dan Dialah yang menciptakan dunia dan segala sesuatu, dengan pengertian lain bahwa oleh karena Dia (Yesus) dunia dan segala sesuatu diciptakan (Yohanes 1:3), kebenaran Alkitab menyatakan bahwa hanya Allahlah yang dapat menciptakan, jadi kalau di sini dikatakan Firman itu (Yesus) menciptakan segala sesuatu, berarti Yesus adalah Sang Pencipta dan Yesus adalah Allah. ${ }^{52}$

Selanjutnya, berkaitan dengan Yesus disebut 'Sulung' atau prototokos dalam perspektif 'yang awal' dari segala yang diciptakan (Kolose 1:15) ini merupakan peranan 'Yesus sebagai Anak Sulung atau prototokos' yang harus mati untuk menghapus atau

\footnotetext{
${ }^{50} \mathrm{http} / / / \mathrm{www}$. geocities.conilrefortned 1710V 071 ent/saksivehova.html

${ }^{51}$ Ibid.

${ }^{52}$ Stephen Tong. Op. Cit., 65.
} 
menebus dosa umat manusia dan keselamatan akan datang dari-Nya. ${ }^{53}$ Oleh karena itu, kebenaran Alkitab menyatakan dengan jelas akan karya penebusan Yesus sebagai Juruselamat umat manusia, di mana konsep penebusan adalah penting sekali bagi pemahaman orang percaya yaitu tentang hubungan Yesus Kristus sebagai Anak Sulung yang mati di atas kayu salib dengan keselamatan umat manusia, karena itu, Allah menetapkan Yesus Kristus agar orang percaya akan memandang ke depan kepada "Kurban" persembahan yang terbaik (Ibrani 10:1-14) dan Yesus Kristus sebagai 'Kurban persembahan yang terbaik' ini merupakan bukti kebenaran Alkitab yang menyatakan bahwa Yesus adalah Juruselamat umat manusia. $^{54}$

Bahkan, di dalam Perjanjian Lama 'Kurban' itu terutama dikaitkan dalam hubungannya dengan urusan dosa, pada zaman Perjanjian Lama setiap orang yang melakukan pelanggaran atau dosa harus mengadakan penebusan atau pendamaian untuk pengampunan atas dosa mereka dan sarana yang dijadikan sebagai kurban adalah binatang, binatang yang dikurbankan harus dibunuh untuk menggantikan manusia si pelanggar agar dosa-dosanya diampuni dan binatang yang dikurbankan adalah binatang yang terbaik tidak boleh bercatat cela. ${ }^{55}$ Sebab itu, di dalam Perjanjian Baru mengangkat pokok pikiran 'Kurban' untuk menjelaskan konsep penebusan Anak Sulung yang ditujukan kepada kematian Yesus Kristus sebagai Juruselamat yang menebus dosa umat manusia (1 Kor 15:3), karena Alkitab dengan jelas menyatakan bahwa Yesus adalah sebagai 'Kurban persembahan yang terbaik dan tidak bercacat cela (2Kor. 5:21; Ibr 4:15)' dan Paulus menuliskan bahwa perbuatan kebenaran satu orang menghasilkan pembebasan semua orang (Rm. 5:18). ${ }^{56}$

Oleh karena itu, pandangan teologis Saksi Yehuwa merupakan pandangan yang salah, karena Saksi Yehuwa menyatakan bahwa Yesus bukanlah Juruselamat umat manusia karena kematian Ye sus adalah sebagai tebusan untuk membayar dan membebaskan manusia dari dosa Adam saja dan bukan dosa seluruh umat manusia. ${ }^{57}$ Bahkan, Saksi Yehuwa tidak menerima karya penebusan Yesus sebagai kunci keselamatan seluruh umat manusia, tetapi keselamatan manusia adalah usaha amal baik manusia itu sendiri dengan menjadi pengikut Saksi Yehuwa yang rajin memberitakan ajaran Saksi Yehuwa dan Iman hanya

${ }^{53}$ Halim Wiryadinata. Op. Cit., 68.

${ }^{54}$ William W. Menzies \& Stanley M. Horton. Op. Cit., 97.

${ }^{55}$ W.R.F. Browning., A Dictionary of the Bible (Cetakan Pertama. Jakarta: BPK Gunung Mulia, 2007),

211.

56 Ibid.

${ }^{57}$ Anonimus., Apa Yang Sebenarnva Alkitab Ajarkan (Jakarta: Perkumpulan Siswa-Siswa Alkitab, 2005), 51 . 
sekedar mempercayai keadaan demikian serta menyerahkan diri sebagai Saksi Yehuwa, sebagaimana yang dinyatakan oleh Charles T. Russel:

Mereka harts dicelikkan dari kebutaan dan dari kematian sehingga mereka masing-masing unit\& dirinya sendiri memperoleh kesempatan penuh unit\& membuktikcm dengan ketaatan maupun ketidaktaatan, kelayakannya untuk hidup keka1. ${ }^{58}$ Bahkan berkaitan dengan yang di atas, Saksi Yehuwa dalam buku 'Karena Allah Itu Benar Adanya' juga menyatakan bahwa: " . mereka yang ingin dirinya diselamatkan dari maut karena sengat claw haruslah mencari penerangan bagi diri sendiri mengencti rahmat Allah dalam Kristus Yesus lalu menanith irnan akan persediaan yang telah dibikinnya. Iman ini berarti mempercayai dengan teguh akan persediaan demikian, memberi segala pupal! kepada Allah karenanya dan lulu memperlihatkan keyakinan ini dengan menyerahkan kepada Allah serta memberitakan mengencti tebusan itu kepada orang-orang. ${ }^{59}$

Dari pernyataan di atas memberikan pemahaman bahwa untuk memperoleh keselamatan manusia hams berusaha sendiri, karena jalan untuk memperoleh keselamatan telah dibuka dengan karya penebusan melalui kematian Yesus Kristus membebaskan manusia dari dosa Adam, sehingga tersedia kesempatan bagi manusia untuk sungguhsungguh berupaya mencapai keselamatan dengan menjadi pengikut Saksi Yehuwa dan dengan setia memberitakan pengajaran Saksi Yehuwa kepada orang lain.

Maka, jelaslah bahwa pandangan Saksi Yehuwa merupakan pandangan yang salah karena bertentangan dengan kebenaran Alkitab. Sebaliknya, pandangan teologi Kristen Protestan merupakan pandangan yang benar, karena teologi Kristen Protestan menyatakan bahwa di dalam Alkitab baik Perjanjian Lama maupun Perjanjian Baru menyatakan bahwa karya penebusan Yesus Kristus merupakan pembayaran tebusan bagi seluruh dosa umat manusia dan melalui pengorbanan Kristus telah tersedia Keselamatan bagi semua orang yang percaya kepada-Nya, sebagaimana yang dijelaskan oleh Charles C. Ryrie di dalam bukunya yang menyatakan bahwa: Karya penebusan Yesus Kristus merupakan tebusan bagi seluruh dosa manusia dan Keselamatan itu berpusat pada Pribadi yang paling besar yaitu Tuhan Yesus Kristus, oleh pengorbanan-Nya tersedia keselamatan bagi semua orang yang mau percaya kepada-Nya; keselamatan bersifat

${ }^{58}$ Charles Taze Russel. 1988. Studies in Scripture. Volume I. him 158.

59133 Karena Allah Itu Benar Adanya. Op. Cit. hlm. 125. 
perorangan atau pribadi. Karena itu, keselamatan merupakcot tema dalam Alkitab baik dalam Perjanjian Lama maupun dalam Perjanjian Baru. ${ }^{60}$

Dari pernyataan di atas memberikan pemahaman bahwa karya penebusan Yesus Sang Mesias adalah menghapus sepenuhnya dosa umat manusia dan tersedia keselamatan bagi mereka yang mau percaya kepada-Nya, karena dari sudut pandangan Allah keselamatan meliputi segenap karya Allah dalam membawa manusia keluar dari hukuman menuju pembenaran dan dari kematian kepada kehidupan keka1. ${ }^{61}$

\section{Kesimpulan}

Jadi Alkitab dengan jelas menyatakan bahwa Yesus Kristus sebagai `Anak Sulung atau prototokos' yang telah mati untuk menebus dosa umat manusia dan melalui penebusan Yesus Kristus telah tersedia keselamatan bagi semua orang yang percaya kepadaNya (Kisah Para Rasul 4:12). ${ }^{62}$

\footnotetext{
${ }^{60}$ Charles C. Ryrie. Op. Cit., 15.

${ }^{61}$ Ibid.

${ }^{62}$ J. Verkuyl.. Aku Percaya: Uraian tentang Injil. (Jakarta: BPK Gunung Mulia, Cetakan I, 1954)
} 